\title{
QbD APPROACH IN THE DEVELOPMENT OF ORAL LYOPHILISATES WITH IBUPROFEN FOR PAEDIATRIC USE
}

\author{
ȘTEFANA SUCIU ${ }^{1}$, SONIA IURIAN ${ }^{1}{ }^{*}$, CATĂLINA BOGDAN ${ }^{2}$, RAREȘ IOVANOV $^{1}$, LUCIA $^{2}$ \\ RUS $^{3}$, MIRELA MOLDOVAN ${ }^{2}$, IOAN TOMUȚA ${ }^{1}$
}

\author{
"Iuliu Hațieganu" University of Medicine and Pharmacy, Faculty of Pharmacy, Cluj-Napoca, Romania \\ ${ }^{I}$ Department of Pharmaceutical Technology and Biopharmacy, 41 V. Babeș Street, 400012 \\ ${ }^{2}$ Department of Dermatology and Cosmetics, 12 I. Creangă Street, 400010 \\ ${ }^{3}$ Department of Drug Analysis, 6 L. Pasteur Street, 400349
}

*corresponding author: iuriansonia@yahoo.com

Manuscript received: January 2018

\begin{abstract}
Quality-by-Design (QbD) concept in drug formulation and development was introduced in order to achieve and ensure an adequate product quality through a good process understanding. By identifying the variability sources that influence the product features, the quality of the product can be built from the development phase. Applying the concept, in the current work it was intended to develop and characterize orodisperable lyophilisates (OLs) for paediatric use. The drug model used was ibuprofen and following risk assessment evaluation, twenty-five experimental formulations were prepared. With a Doptimal experimental design with six factors and two levels, the influence of the formulation factors on the desired quality target product profile was assessed (QTPP, the quality characteristics of a product that is intended to be achieved considering the aspects related to the safety and efficacy of the product): disintegration time, wetting time, mean dissolution time, texture and bio-adhesive features of the OLs were studied. During this experiment, it was observed that the type of the matrix forming and bio-adhesive agent influenced the disintegration time. All formulation factors influenced the wetting time, while no significant influence was observed for the bio-adhesive properties of the OLs. The hardness and rigidity of the OLs was increased by gelatine, while the methylcellulose and xanthan gum conducted to opposite results. The fracturability of the OLs was influenced only by the quantitative factors, respectively the percentage of the matrix forming agent and the bio-adhesive agent. The dissolution profile was slightly influenced by the type of bio-adhesive agent. The design space has been defined based on the obtained results. The QbD approach was successfully applied within this study and OLs with ibuprofen for paediatric use with desired pharmaceutical characteristics may be successfully obtained by lyophilisation.
\end{abstract}

\section{Rezumat}

Conceptul de calitate prin design (QbD) a fost introdus în formularea şi dezvoltarea medicamentelor cu scopul de a obține şi asigura o calitate adecvată a produsului, printr-o bună înțelegere a procesului. Prin identificarea surselor de variabilitate care influențează caracteristicile produsului, calitatea produsului poate fi construită din faza de dezvoltare a acestuia. Aplicând acest concept, în prezenta lucrare s-a urmărit dezvoltarea şi caracterizarea liofilizatelor orale, concepute pentru uz pediatric. Ca şi substanţă model, s-a utilizat ibuprofenul, preparându-se douăzeci şi cinci de formulări pe baza unui model experimental D-optimal, cu şase factori şi două niveluri. S-a studiat influența factorilor de formulare asupra profilului de calitate dorit (QTPP - caracteristicile de calitate dorite ale produsului, ținând cont de siguranța și eficacitatea acestuia): timpul de dezintegrare, timpul de umectare, timpul mediu de dizolvare, textura şi caracteristicile bio-adezive ale liofilizatelor. Principalele observații au fost: tipul formatorului de matrice și a agentului bio-adeziv care au influențat timpul de dezintegrare a liofilizatelor; toți factorii de formulare au influențat timpul de umectare, dar nu s-a observat o influență semnificativă asupra proprietăţilor bio-adezive conferite. Utilizarea gelatinei a condus la obținerea unor structuri mai rezistente, în timp ce utilizarea gumei xantan sau a metilcelulozei a condus la obținerea unor structuri fragile. Rata de fracturare a liofilizatelor a fost influențată doar de factori cantitativi, precum procentul formatorului de matrice și procentul de bio-adeziv utilizat. Profilul de dizolvare al liofilizatelor a fost ușor influențat de tipul polimerului bio-adeziv utilizat. Domeniul optim a fost definit în urma rezultatelor obținute. Conceptul de QbD a fost aplicat cu succes în cadrul acestui studiu, iar comprimatele orodispersabile cu ibuprofen pentru uz pediatric au arătat caracteristici de calitate dorite, ce pot fi obținute cu succes prin liofilizare.

Keywords: orodispersable tablets, paediatric drugs, pharmaceutical development, Quality-by-Design (QbD)

\section{Introduction}

Recent recommendations of the European Medicine Agency (EMA) and World Health Organization (WHO) concerning the paediatric dosage forms are referring to development of formulations that require minimum handling before administration. In addition to that, it is recommended to develop flexible dosage forms, with emphasis on the easy drug administration $[3,19]$. The oral route represents the most common 
route of drug administration; self-medication, accurate dosing, lack of pain, low cost and patient compliance are the main reasons for choosing this route when possible [18]. Often, for paediatric use, liquid forms are available; however, the patients confront the difficulty of reconstitution and application, in the context of dosing devices, special storage and the handling conditions needed [20].

Due to the ease of administration and swallowing, the focus was directed on the orally disintegrating dosage forms. They have been developed in order to overcome the drawbacks of conventional oral dosage forms.

Their main advantage consists in the lack of water consumption during administration. Following the contact with the saliva, the oral lyophilisate (OL) is rapidly dissolving or disintegrating in the oral cavity with the release of the drug for absorption [13].

Ibuprofen, a well-known molecule that is frequently used for different conditions associated with pain or febrile states, is marketed for wide ranges of population, as different dosage forms and strengths and it is classified as an over-the-counter drug. In paediatrics, ibuprofen is one of the most used molecules in order to manage the febrile states as liquid formulations for infants and toddlers and tablets or capsules for children $[5,16]$. It is a nonsteroidal anti-inflammatory drug, for which the development of orally disintegrating tablets has been carried out, but to our knowledge, not by freeze-drying [6].

The Quality by Design concept (QbD) implies an indepth knowledge and understanding of the technological process for a specific pharmaceutical dosage form. It involves the analysis, understanding and control of all sources of error, following the assumption that each step of the process is a possible source of variability [10]. The existing guideline intended for pharmaceutical development (ICH Q8 - International Conference on Harmonisation of Technical Requirements for Registration of Pharmaceuticals for Human Use) defines this concept as being a structured path for development, based on risk assessment analysis entailing the predefined objectives, profound understanding of the process and product and a well-established process control [8]. This concept gained the attention of the researchers and pharmaceutical industry due to its benefits and it has already been adopted as a viable strategy in drug development [12]. By applying this concept, the relationships between the formulation, the process variables and desired quality features of the pharmaceutical product are well defined, allowing the establishment of the design space, thus ensuring that the required characteristics are fulfilled [4].

The aim of the present study was the development and optimization of oral lyophilisates (OLs) with ibuprofen for paediatric use, by using the quality by design approach in each formulation step. The research work was performed using experimental design in order to develop a formulation with appropriate mechanical properties, short disintegration time and fast dissolution. Moreover, as a novelty element, bioadhesive agents were included in the study, with the aim of ensuring the temporary attachment to the oral mucosa up to the disintegration. Our initiative was meant to enable a safe solid dosage form administration to paediatric patients of all ages, by preventing choking or aspiration events.

Commonly, the bio-adhesive polymers are used for prolonged release dosage forms but in the context of paediatric administration, the retention on the oral mucosa of the rapid disintegrating dosage form would be a benefit that favours the avoidance of unwanted swallowing incidents.

\section{Materials and Methods}

\section{Materials}

Ibuprofen (BASF, Ludwigshafen, Germany) was used as active substance. Methylcellulose (MC) 1500 (Serva, Germany), xanthan gum, Rhodigel 200 (Rhodia, USA), gelatine and sodium alginate (Alginic acid sodium salt from brown algae, Sigma Aldrich, USA) were used as matrix forming agents. As bio-adhesive agents were used: carbopol (Noveon, USA), polycarbophyl (Lubrizol Advance Materials Europe, Belgium), polivinylpirolidone (PVP) K25 (Merck, Germany), HPMC Methoce $^{\mathrm{TM}} \mathrm{K} 4 \mathrm{M}$ (Colorcon, USA) and polyox (Union Carbide, USA). The filling agents selected for this study were mannitol (Merck, USA), isomalt (Palatinit $\mathrm{GmbH}$, Germany), trehalose dyhydrate (Sigma Aldrich, USA), lactose (Merck, Germany) and sucrose (Sigma Aldrich, USA). As a solvent, distilled water was used. Quality by Design (QbD) approach for OLs development

Identification of Quality Target Product Profile (QTPP), Critical Quality Attributes (CQAs) and assessment of risk factors. According to the existing ICH Q8 (2) guideline, the QTPP contains the features that have direct correlation to the quality, safety and efficacy attributes of the pharmaceutical product. Table I lists the QTPP for the OLs with ibuprofen. The review of existing literature, preliminary studies and the quality attributes of the product represents the starting point for defining the CQAs of the product. Based on these considerations, the CQAs of the formulation are represented by the texture features, disintegration time and dissolution profile.

For the CQAs' assurance, Ishikawa diagrams were used as tools for risk assessment analysis and identification of the potential variables that might influence the quality attributes. Six variables were selected, included in experimental design and further studied. 
QTPP of ibuprofen oral lyophilisates

\begin{tabular}{lcc}
\hline \multicolumn{1}{c}{ QTPP element } & Target & Observations \\
\hline Route of administration & Oral & \\
Dosage form & Orally disintegrating OLs & Disintegration time less than 3 minutes \\
Dosage strength & $25 \mathrm{mg}$ & No physical defects, uniformity between different \\
Drug product quality attributes & Physical properties & units, no signs of structure collapse \\
& Assay & $95 \%-105 \%$ \\
& Dissolution & Minimum $90 \%$ within $180 \mathrm{~s}$ \\
Container closure system & Suitable for storage in normal conditions & Ensure product integrity during shelf life \\
\hline
\end{tabular}

\section{Design of Experiments (DoE)}

The design was conceived using Modde 11 Pro software (Umetrics, Sweden). The independent variables selected based on the risk analysis were the percentage (X1) and the type of matrix forming agent (X2), the percentage (X3) and the type of bio-adhesive agent (X4) and the percentage (X5) and the type of filler (X6), as shown in Table II. The matrix forming agents (X2) were: methylcellulose, xanthan gum, gelatine and sodium alginate, which varied on two levels, as mentioned in the design matrix. The bioadhesive agents were carbopol, polycarbophyl, PVP K25, HPMC and Polyox, which also varied on two levels. Mannitol, isomalt, trehalose, lactose and sucrose were selected as fillers, at concentrations ranging from $0 \%$ to $10 \%$. A D-Optimal screening experimental design was generated, with 22 runs and three centre points. Twenty-five formulations were prepared, as shown below, in Table II.

Table II

Experimental design matrix

\begin{tabular}{|c|c|c|c|c|c|c|c|}
\hline Exp. Name & Run Order & $\mathrm{X} 1$ & $\mathrm{X} 2$ & X3 & $\mathrm{X4}$ & $\mathrm{X5}$ & X6 \\
\hline N1 & 23 & 1 & Methylcellulose & 0 & Carbopol & 0 & Mannitol \\
\hline N2 & 7 & 0.1 & Xanthan gum & 0 & Polycarbophyl & 10 & Mannitol \\
\hline N3 & 10 & 2.5 & Gelatine & 2 & PVP K25 & 10 & Mannitol \\
\hline N4 & 5 & 1 & Sodium Alginate & 0.5 & HPMC & 0 & Mannitol \\
\hline N5 & 1 & 0.3 & Xanthan gum & 0.4 & Carbopol & 10 & Isomalt \\
\hline N6 & 9 & 5 & Gelatine & 0 & Polyox & 10 & Isomalt \\
\hline N7 & 25 & 0.1 & Sodium Alginate & 0 & Polycarbophyl & 0 & Isomalt \\
\hline N8 & 16 & 0.5 & Methylcellulose & 2 & PVP K 25 & 0 & Isomalt \\
\hline N9 & 13 & 5 & Gelatine & 0.5 & HPMC & 0 & Isomalt \\
\hline N10 & 6 & 2.5 & Gelatine & 0 & Carbopol & 0 & Trehalose \\
\hline N11 & 11 & 0.1 & Xanthan gum & 1 & Polyox & 0 & Trehalose \\
\hline N12 & 15 & 1 & Methylcellulose & 0.4 & Polycarbophyl & 10 & Trehalose \\
\hline N13 & 3 & 1 & Sodium Alginate & 0 & PVP K25 & 10 & Trehalose \\
\hline $\mathrm{N} 14$ & 21 & 0.1 & Xanthan gum & 0 & HPMC & 10 & Trehalose \\
\hline N15 & 22 & 0.1 & Sodium Alginate & 0.4 & Carbopol & 10 & Lactose \\
\hline N16 & 12 & 1 & Methylcellulose & 0 & Polyox & 10 & Lactose \\
\hline N17 & 17 & 2.5 & Gelatine & 0 & Polycarbophyl & 0 & Lactose \\
\hline N18 & 20 & 0.3 & Xanthan gum & 0.5 & HPMC & 0 & Lactose \\
\hline N19 & 24 & 0.1 & Sodium Alginate & 1 & Polyox & 0 & Sucrose \\
\hline $\mathrm{N} 20$ & 18 & 5 & Gelatine & 0.4 & Polycarbophyl & 10 & Sucrose \\
\hline $\mathrm{N} 21$ & 14 & 0.3 & Xanthan gum & 0 & PVP K25 & 0 & Sucrose \\
\hline N22 & 4 & 0.5 & Methylcellulose & 0 & HPMC & 10 & Sucrose \\
\hline $\mathrm{N} 23$ & 8 & 3.75 & Gelatine & 0.25 & HPMC & 5 & Sucrose \\
\hline $\mathrm{N} 24$ & 2 & 3.75 & Gelatine & 0.25 & HPMC & 5 & Sucrose \\
\hline $\mathrm{N} 25$ & 19 & 3.75 & Gelatine & 0.25 & HPMC & 5 & Sucrose \\
\hline
\end{tabular}

$\mathrm{X} 1$ - percentage of the matrix forming agent; X2 - type of the matrix forming agent; X3 - percentage of the bio-adhesive agent; X4 - type of the bio-adhesive agent; X5 - percentage of the filler; X6 - type of the filler

\section{Data processing}

The experimental data were fitted with the selected experimental design and by using the statistical module from Modde 11 Pro software. The statistical parameters were calculated with the same software. Data fitting and calculation of statistical parameters were performed by partial least squares (PLS) method. The statistical parameters determined were $\mathrm{R}^{2}$, representing the variation explained by the model, and $\mathrm{Q}^{2}$, the fraction of the variation of the response that can be predicted by the model. Moreover, the validity of the experimental design was checked by the analysis of variance (ANOVA) test.

Preparation of oral lyophilisates

25 suspensions were prepared according to the experimental design matrix, as follows: first, the 
FARMACIA, 2018, Vol. 66, 3

corresponding amounts of matrix forming agent and bio-adhesive agent were dispersed in distilled water, then the filler was dissolved and finally ibuprofen was suspended in the viscous media, up to a content of $50 \mathrm{mg} / \mathrm{mL}$. Volumes of $0.5 \mathrm{~mL}$ of suspension were placed in blister pockets, which were placed on the freeze-drying equipment shelf. The freeze-drying process (Figure 1) was performed using a VirTis Advantage Plus equipment (SP Scientific). Thermal treatment consisted in cooling the shelf at $-55^{\circ} \mathrm{C}$, at a rate of $1^{\circ} \mathrm{C} /$ minute, followed by an annealing step at $-35^{\circ} \mathrm{C}$. Primary drying was performed at $-25^{\circ} \mathrm{C}$, a chamber pressure of $150 \mathrm{mTorr}$, for 36 hours. In order to remove the absorbed water from the product, secondary drying was performed at $15^{\circ} \mathrm{C}$ at $300 \mathrm{mTorr}$ for 10 hours. When the process was done, the OLs were placed in the desiccator at room temperature until the analysis was performed.

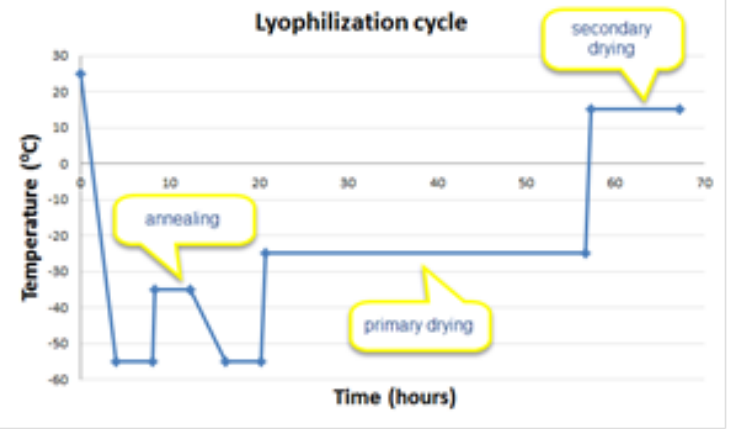

Figure 1.

Lyophilisation cycle (temperature $v s$. time)

Pharmaceutical characterization of the oral lyophilisates In vitro disintegration time (Y1). According to pharmacopoeial method, the OLs were placed in $200 \mathrm{~mL}$ distilled water at the temperature of $37 \pm$ $0.5 \mathrm{C}$ [4]. The time needed for complete disintegration of the OLs was recorded (Y1) using a digital stop-watch on six OLs from each formulation. The mean and standard deviation were calculated.

In vitro dissolution tests (Y2-Y6). The dissolution tests were performed in compliance with European Pharmacopeia requirements [4], using pallets dissolution test (Pharma Test PT-DT7, Germany); the OLs were dissolved into $900 \mathrm{~mL}$ dissolution medium, phosphate buffer $\mathrm{pH}=7.2$; temperature was kept at $37 \pm$ $0.5 \mathrm{C}$ and rotation speed of $50 \mathrm{rpm} .5 \mathrm{~mL}$ samples were taken after 5, 10, 15, 20 and 30 minutes, and the same volume of fresh buffer was added after each sampling. The ibuprofen content was assessed by UV-VIS spectrophotometric measurement at 221 nm (Analytik Jena, Germany). This test was performed on three OLs from each formulation and the average of the dissolved ibuprofen percentage after 5, 10, 15, 20, 30 minutes (Y2-Y6) obtained for each formulation was considered at data analysis.
Texture analysis (Y7-Y13). The mechanical properties of the OLs were characterized by the texture determination, performed with the texture analyser Brookfield CT (Brookfield, Engineering, USA).

The mechanical properties' assessment consisted in a constant pressure applied on OLs, with a cylinder probe having a $50 \mathrm{~g}$ load, $0.01 \mathrm{~mm} / \mathrm{s}$ speed, down to a depth of $1 \mathrm{~mm}$ into the sample structure. The results were recorded as load $v s$. distance curves, representing the resistance of the material to the applied pressure. The measurements were performed using three OLs for each formulation and the average results were considered for data analysis. Using the aforementioned method, the hardness (Y7), the rigidity of the OLs at $1 \mathrm{~mm}$ (Y8) and the fracturability were determined (Y9).

The bio-adhesion properties were evaluated using the same equipment, but in different experimental conditions, as it follows: porcine intestinal tissue was used, obtained from the local slaughterhouse. The OL was placed by adhesion on the cylinder probe, which was previously wrapped into intestinal tissue. On the opposite surface intestinal tissue was placed. The OL descended onto the intestinal tissue surface in a TPA test with 2 cycles, at $0.5 \mathrm{~g}$ trigger load and $0.1 \mathrm{~mm} / \mathrm{s}$ test speed. Its behaviour was observed at the contact between the OL surface and the intestinal tissue surface, as well as at their detachment. As a result, the following parameters were recorded: adhesiveness, resilience and recoverable deformation (Y10 - Y12), as mean values of three measurements and standard deviation.

\section{Results and Discussion}

The main objective of the study was the development and optimization of a dosage form with ibuprofen intended for paediatric use, respectively oral lyophilisates. Secondly, the bio-adhesive properties were assessed, as well as their influence on OLs' CQAs. The quality by design approach was used in each formulation step, with focus on the formulation parameters.

Risk assessment analysis

The quality target product profile was initially defined taking into consideration the dosage form and the preparation method, which was selected at the beginning of this study. The CQAs derived from this preliminary analysis were the texture characteristics, the disintegration time and the dissolution profile of the OLs.

For the risk analysis, Ishikawa diagrams were used (Figure 2), the potential factors that might influence the attributes of the desired products were considered. Factors related to technological process, formulation, instrument reliability and analytical method were evaluated. Instrument reliability and analytical methods were not ranked as highly risky variables, since the instruments are periodically calibrated and qualified and the analytical methods are validated. 
FARMACIA, 2018, Vol. 66, 3

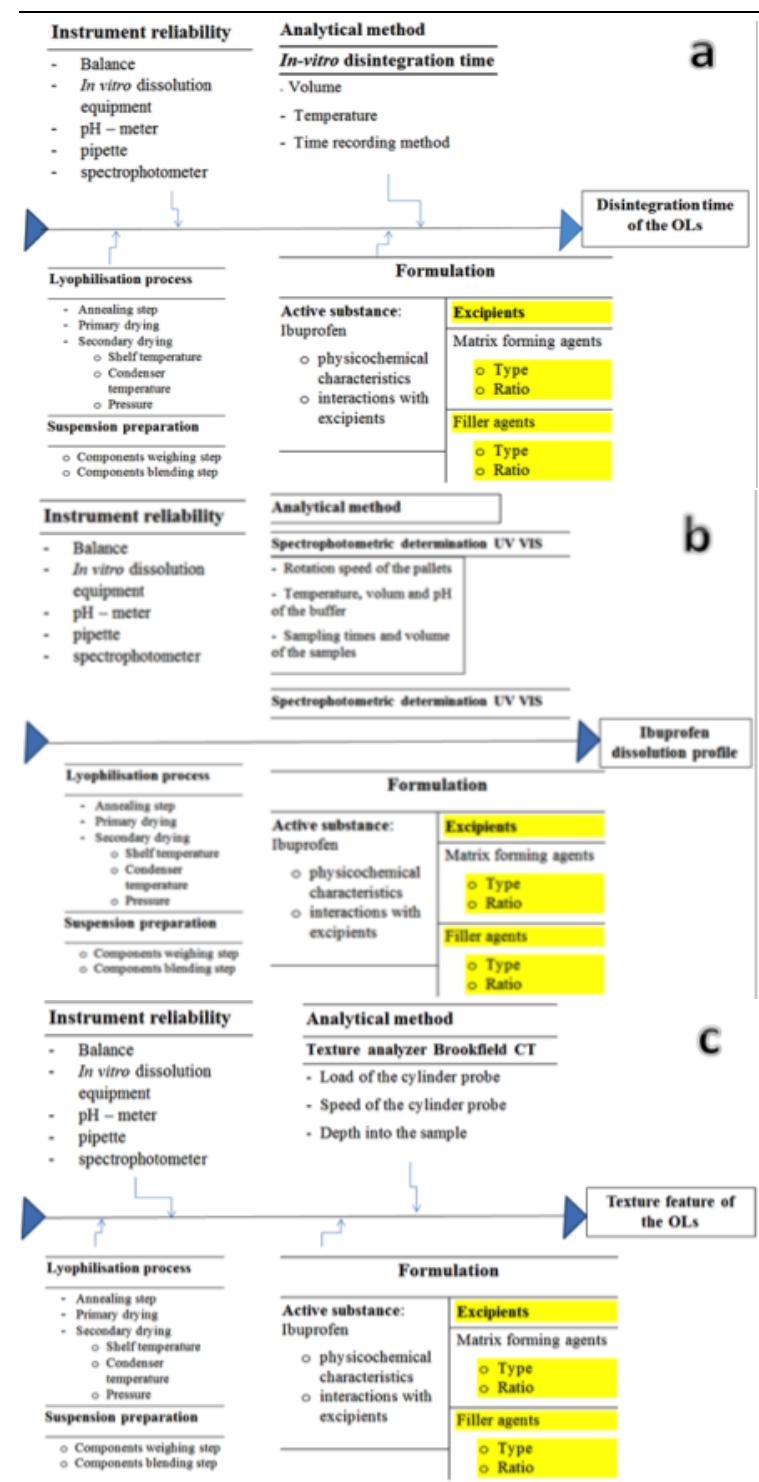

Figure 2.

Ishikawa diagrams for disintegration time (a), dissolution profile (b) and mechanical properties (c) The preparation process consists in two main stages: suspension preparation and lyophilisation. Each stage is controlled in certain ways: the suspension quality depends on the formulation factors, thus polymer dispersion viscosity, while the freeze-drying process parameters were established following thermal analysis.

Further, formulation factors as the type and ratio of matrix forming agent determine the suspension stability and OL homogeneity, OL structure, disintegration and active pharmaceutical ingredient (API) dissolution properties. On the other hand, the type and ratio of filler can influence the mechanical properties, the disintegration and the API dissolution.

Based on the risk assessment stage results, the formulation parameters selected in order to perform the study were the type (X1) and percentage of the matrix forming agent (X2) and the type (X5) and percentage of the filler (X6). The ratios of matrix forming agents were selected based on preliminary experiments (results not shown); so that the final suspensions would be consistent enough to prevent ibuprofen sedimentation and still fluid to be easily poured into blister pockets. The filling agents were used at ratios comprised between $0 \%$ and $10 \%$, to evaluate their influence on OLs' characteristics and bio-adhesive properties.

The bio-adhesive agents were also included into the design of experiments, as the type (X3) and percentage of bio-adhesive agent (X4) and varied on two levels. They were meant to improve the OLs' adhesion to the oral mucosa, without any significant influence on the specific quality features of OLs, disintegration time and ibuprofen dissolution. That is the reason for which their lower level was kept at $0 \%$ in order to assess the CQAs and adhesion properties of the formulations with or without the bio-adhesive agent. The freeze-drying process was defined based on thermal characterization of the suspensions included in the experiment. The glass transition temperatures and the crystallization events of the prepared suspensions in their frozen states (before freeze-drying) were studied by differential scanning calorimetry (results not shown). DoE analysis

For data analysis, the results presented in the Table III were considered. Each formulation was tested and the results are listed below for each response.

Table III

Response Matrix

\begin{tabular}{ccccccccccccc}
\hline Exp. Name & Y1 & Y2 & Y3 & Y4 & Y5 & Y6 & Y7 & Y8 & Y9 & Y10 & Y11 & Y12 \\
\hline N1 & 582.5 & 71.3 & 79.1 & 84.4 & 85.8 & 88.7 & 2.1 & 0.6 & 2.1 & 0.08 & 0.12 & 0.23 \\
N2 & 2.74 & 24 & 46.5 & 67.9 & 74.7 & 75.8 & 3.6 & 2.4 & 1.7 & 0.05 & 0.15 & 0.12 \\
N3 & 749.33 & 99.6 & 108.4 & 107.9 & 107.4 & 106.9 & 23.6 & 6.4 & 14.5 & 0.04 & 0.23 & 0.17 \\
N4 & 91.83 & 35.1 & 68.5 & 87.1 & 96.4 & 97.5 & 2.1 & 0.8 & 2.1 & 0.08 & 0.17 & 0.24 \\
N5 & 5.37 & 12.2 & 27.5 & 40.2 & 54.1 & 60.7 & 22.1 & 5.2 & 22.1 & 0.06 & 0.09 & 0.1 \\
N6 & 657 & 64.7 & 103.2 & 116 & 118.2 & 118 & 43.9 & 21.3 & 34.9 & 0.03 & 0.22 & 0.25 \\
N7 & 7.3 & 107.4 & 104.5 & 104 & 104 & 103.2 & 52.8 & 18.4 & 52.8 & 0.04 & 0.11 & 0.04 \\
N8 & 12.48 & 41.7 & 58.7 & 70.6 & 72.3 & 74.9 & 1.2 & 0.3 & 0.2 & 0.06 & 0.07 & 0.14 \\
N9 & 1700 & 57 & 90.4 & 105.2 & 111.3 & 115.7 & 35.5 & 5 & 35.5 & 0.04 & 0.2 & 0.14 \\
N10 & 397.67 & 114.8 & 115.6 & 115.5 & 115.9 & 115.4 & 16.3 & 6 & 16.3 & 0.06 & 0.11 & 0.31 \\
N11 & 133.67 & 14.6 & 22.2 & 29.2 & 38.7 & 53.1 & 1.2 & 0.3 & 1 & 0.07 & 0.08 & 0.08 \\
N12 & 64.67 & 11.9 & 20.3 & 34.7 & 43.4 & 59.6 & 26.8 & 9.3 & 10.5 & 0.06 & 0.05 & 0.07 \\
N13 & 3.81 & 93.2 & 99.5 & 99.3 & 98.9 & 99 & 7.6 & 1.3 & 0.4 & 0.03 & 0.04 & 0.06 \\
\hline
\end{tabular}


FARMACIA, 2018, Vol. 66, 3

\begin{tabular}{ccccccccccccc}
\hline Exp. Name & Y1 & Y2 & Y3 & Y4 & Y5 & Y6 & Y7 & Y8 & Y9 & Y10 & Y11 & Y12 \\
\hline N14 & 1.77 & 53 & 68.7 & 74.2 & 78.5 & 83.5 & 17.1 & 6.7 & 3.6 & 0.02 & 0.08 & 0.03 \\
N15 & 17.67 & 26.5 & 44.7 & 52.2 & 56.9 & 60.5 & 4.4 & 3 & 3.1 & 0.04 & 0.06 & 0.13 \\
N16 & 3.33 & 50.4 & 60.6 & 67.3 & 69.8 & 80.9 & 5.5 & 2.6 & 5.3 & 0.05 & 0.1 & 0.18 \\
N17 & 334.83 & 93.7 & 107.9 & 107 & 106.8 & 106.4 & 22.6 & 7.2 & 22.6 & 0.03 & 0.19 & 0.15 \\
N18 & 139.33 & 6.9 & 10.1 & 12.7 & 14.5 & 18.2 & 2.3 & 1 & 2.3 & 0.16 & 0.06 & 0.15 \\
\hline
\end{tabular}

Y1 - Disintegration time; Y2 - Dissolution \% 5 min; Y3 - Dissolution \% 10 min; Y4 - Dissolution \% 15 min; Y5 - Dissolution \% 20 min; Y6 - Dissolution \% 30 min; Y7 - Hardness (N); Y8 - Rigidity 1 mm (N); Y9 - Fracturability (N); Y10 - Adhesiveness; Y11 - Resilience; Y12 - Recoverable deformation

\section{Quality of fit}

The statistical analysis, presented in Table IV, pointed out significant models for all the responses. The revised values of the regression coefficients of the model equations are presented as histograms (Figure 3). The coefficient values indicate the magnitude of the effects of formulation variables on the responses, while their sign indicates a positive or a negative influence on the response. The $\mathrm{R}^{2}$ coefficient was above 0.9 for responses $\mathrm{Y} 7, \mathrm{Y} 8$ and Y11 and between 0.633 and 0.875 for the rest, which shows a good fit of the experimental data to the developed models.

Table IV

Statistical parameters - variance test analysis

\begin{tabular}{ccccccccc}
\hline Response & SS & MS & DF & F-value & $\mathbf{p}$ & $\mathbf{R}^{\mathbf{2}}$ & Adjusted $\mathbf{R}^{\mathbf{2}}$ & $\mathbf{Q}^{\mathbf{2}}$ \\
\hline Y1 & 94.6926 & 4.11707 & 12 & 8.4229 & 0.001 & 0.875 & 0.771 & 0.45 \\
Y2 & 99469.4 & 3978.78 & 18 & 8.12169 & 0.000 & 0.73 & 0.640 & 0.426 \\
Y3 & 155666 & 6226.65 & 18 & 12.843 & 0.000 & 0.811 & 0.748 & 0.511 \\
Y4 & 185870 & 7434.81 & 18 & 9.30546 & 0.000 & 0.756 & 0.675 & 0.383 \\
Y5 & 198018 & 7920.71 & 17 & 6.11021 & 0.001 & 0.716 & 0.598 & 0.246 \\
Y6 & 208559 & 8342.35 & 16 & 4.29856 & 0.006 & 0.682 & 0.524 & 0.208 \\
Y7 & 24.163 & 1.00679 & 8 & 22.923 & 0.000 & 0.977 & 0.935 & 0.492 \\
Y8 & 11.5108 & 0.47962 & 15 & 18.0264 & 0.000 & 0.906 & 0.856 & 0.586 \\
Y9 & 19.6319 & 0.818 & 13 & 5.93903 & 0.002 & 0.820 & 0.682 & 0.136 \\
Y10 & 0.1023 & 0.00426 & 13 & 6.08846 & 0.002 & 0.824 & 0.689 & 0.594 \\
Y11 & 0.4729 & 0.01892 & 13 & 17.8506 & 0.000 & 0.938 & 0.885 & 0.693 \\
Y12 & 0.93 & 0.0372 & 15 & 2.87674 & 0.034 & 0.633 & 0.413 & 0.249
\end{tabular}

$\mathrm{SS}$ - sum of squares; MS - mean of square; DF - degrees of freedom; F -value - Fischer`s ration; $p$ - probability; $\mathrm{R}^{2}$ - coefficient of determination; Adjusted $\mathrm{R}^{2}$ - adjusted value of the coefficient of determination; $\mathrm{Q}^{2}$ - predictive power of the model

In vitro disintegration time (Y1)

The disintegration times ranged between $1.77 \mathrm{~s}$ and more than 10 minutes. During the tests, it was observed that some of the OLs floated and the moistening was not appropriate. This phenomenon occurred especially for the formulations containing gelatine and it was confirmed by data analysis. It appeared that disintegration time was influenced by all the formulation factors (Figure 3). The use of gelatine determined prolonged disintegration. Similar results are described in the existing literature; it was noticed that increasing the gelatine concentration, the disintegration time extended [14], respectively by increasing the gelatine concentration, the mechanical properties were enhanced but in the same time, the disintegration profile was prolonged to the unacceptable results [2]. On the contrary, the use of sodium alginate and xanthan gum determined a faster disintegration time of the OLs, down to 3.81 respectively $1.77 \mathrm{~s}$. This behaviour was observed previously in similar studies and it is assigned to the porosity of the structures; a high porosity of the structure allows the water ingress and conducts to a rapid disintegration time [15].

Regarding the bio-adhesive agents, the use of polyox determined a longer disintegration time comparing with the use of PVP that shortened it. The filler addition led to quicker disintegration, with no significant difference between the chosen agents, probably due to their highly hydrophilic character that enables fast water uptake. 

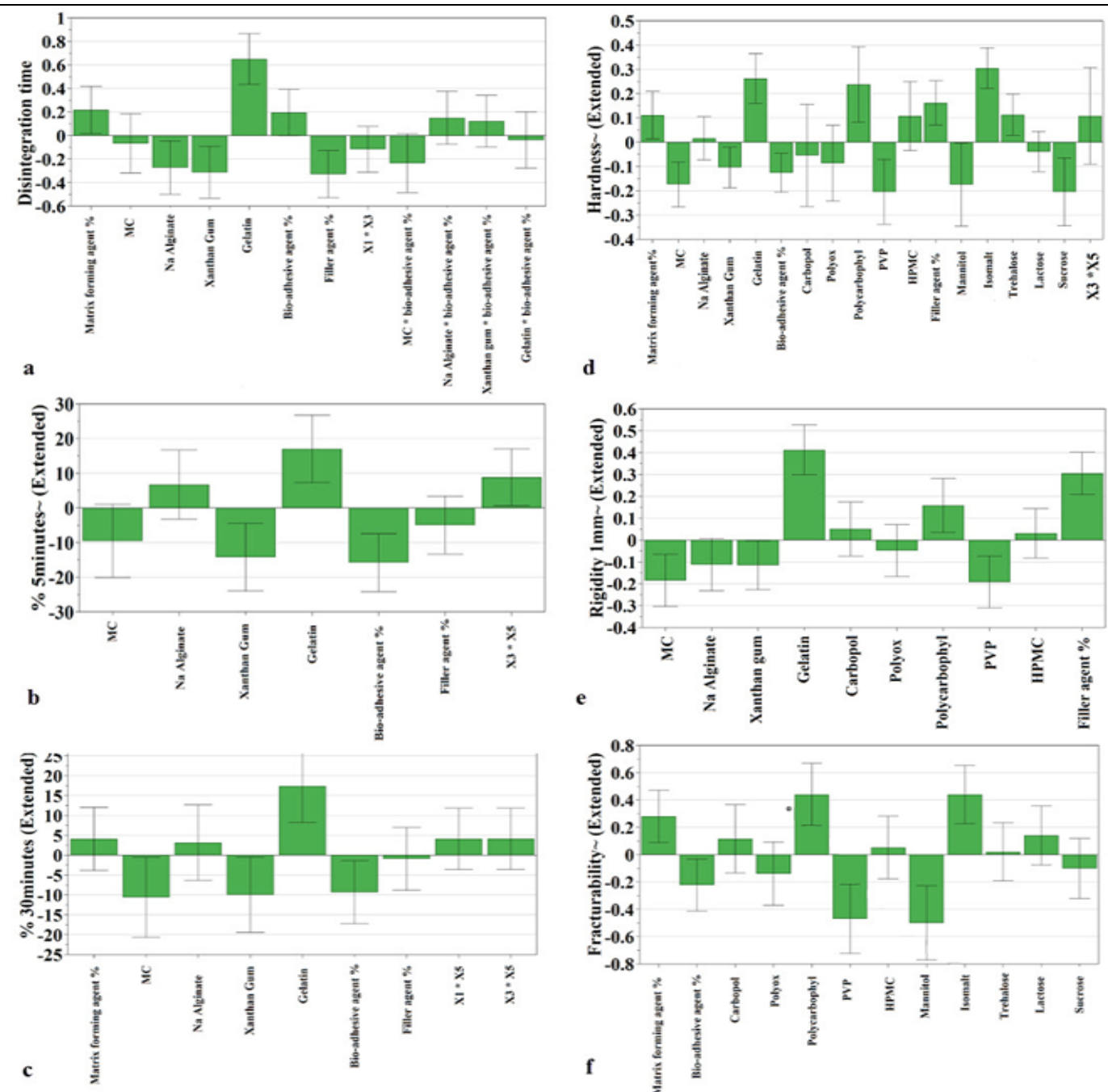

Figure 3.

Influence of the factors on the disintegration time (Y1) (a), ibuprofen dissolution at 5 min (Y2) (b), ibuprofen dissolution at $30 \mathrm{~min}(\mathrm{Y} 6)(\mathrm{c})$, hardness of the OL (Y7) (d), rigidity of the OLs at 1mm (Y8) (e), fracturability of the OLs (Y9) (f)

In vitro dissolution test (Y2-Y6)

Figure 4 shows the dissolution profiles of formulations with disintegration times lower than $180 \mathrm{~s}$ and the percentage of dissolved ibuprofen after 30 minutes above $75 \%$.

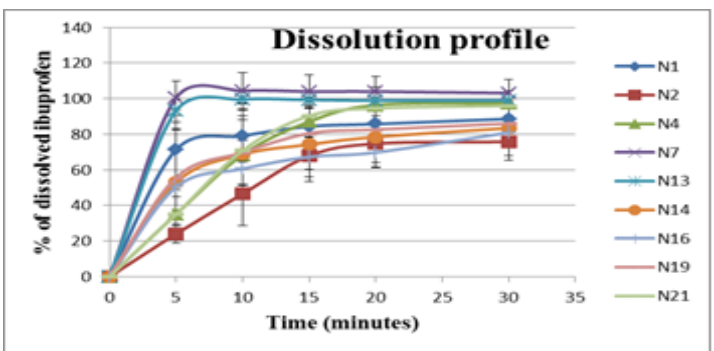

Figure 4.

Dissolution profiles of ibuprofen from selected OL formulations

The influences of the formulation factors on the API dissolution are presented in the Figure $3(\mathrm{~b}, \mathrm{c})$; the effects of formulation factors on API dissolution after
5 minutes and 30 minutes were considered relevant, since for the fast dissolving dosage forms, the quick dissolution and absorption, as well as the complete drug dissolution are of paramount importance. Apparently, the dissolution rates were mostly influenced by the type of matrix forming agent used. Although gelatine OLs were not compliant with the specified disintegration time, data reveals its positive influence on dissolution. The active principle was released without altering the integrity of the structure that kept floating in the dissolution media. The spongy texture of these formulations allows the release of the active substance through the $3 \mathrm{D}$ network that is created between the gelatine fibres [3]. The use of methylcellulose and xanthan gum had the opposite influence on the dissolution; this matrix forming agents negatively influenced it. Low rate of the dissolution for xanthan gum in comparison with gelatine is reported in literature [7].

Although the sodium alginate does not have a significant influence when compared with the other 
FARMACIA, 2018, Vol. 66, 3

matrix forming agents, it also led to appropriate dissolution profiles (formulations N7 and N13), with over $90 \%$ ibuprofen released after 5 minutes.
The presence of high amounts of bio-adhesive agents and fillers conducted to prolonged dissolution.

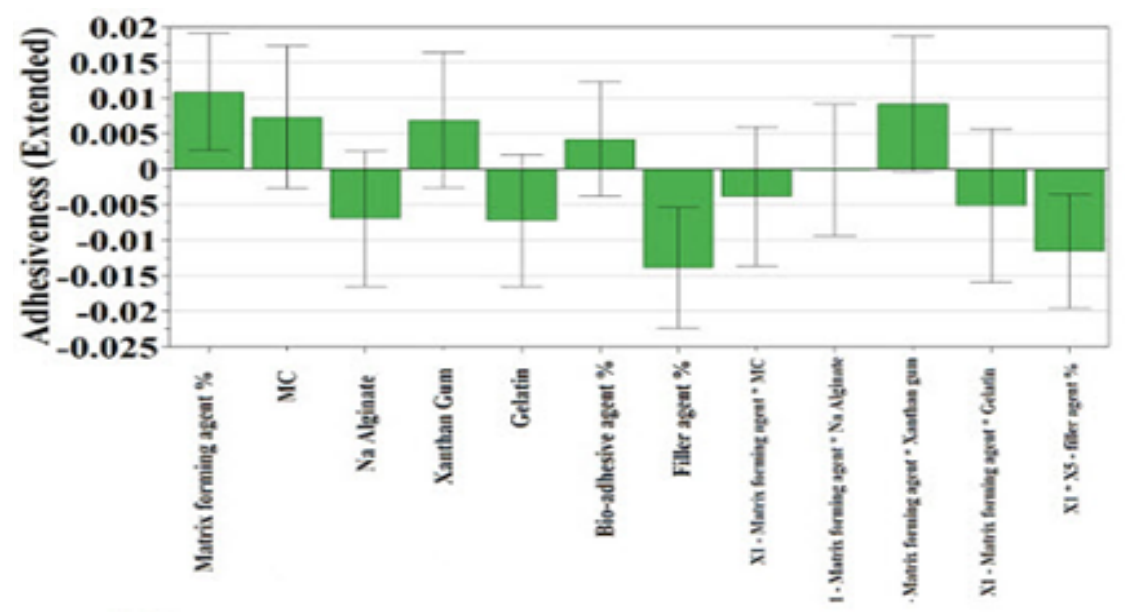

a

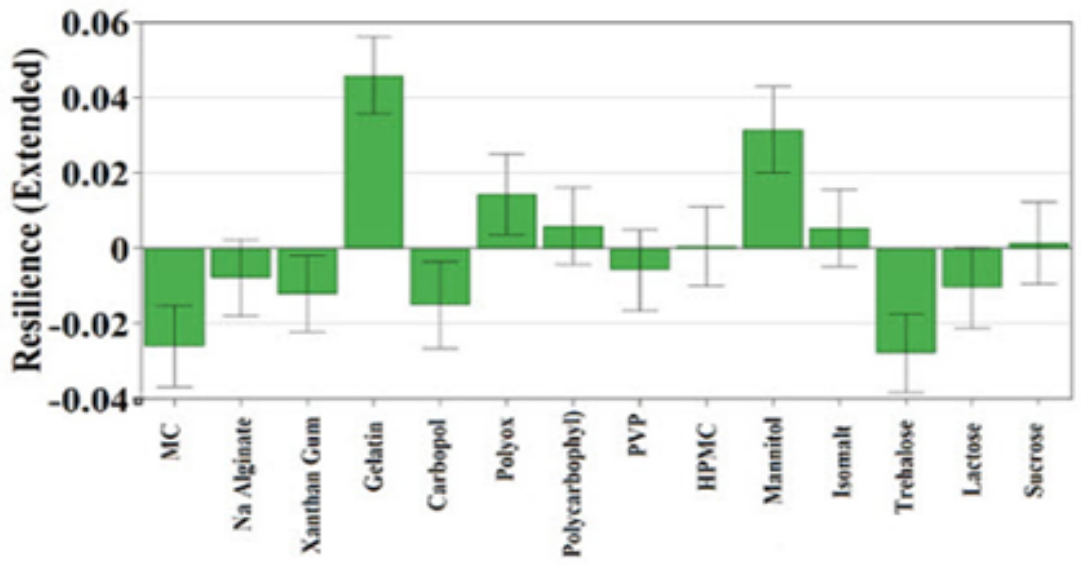

b

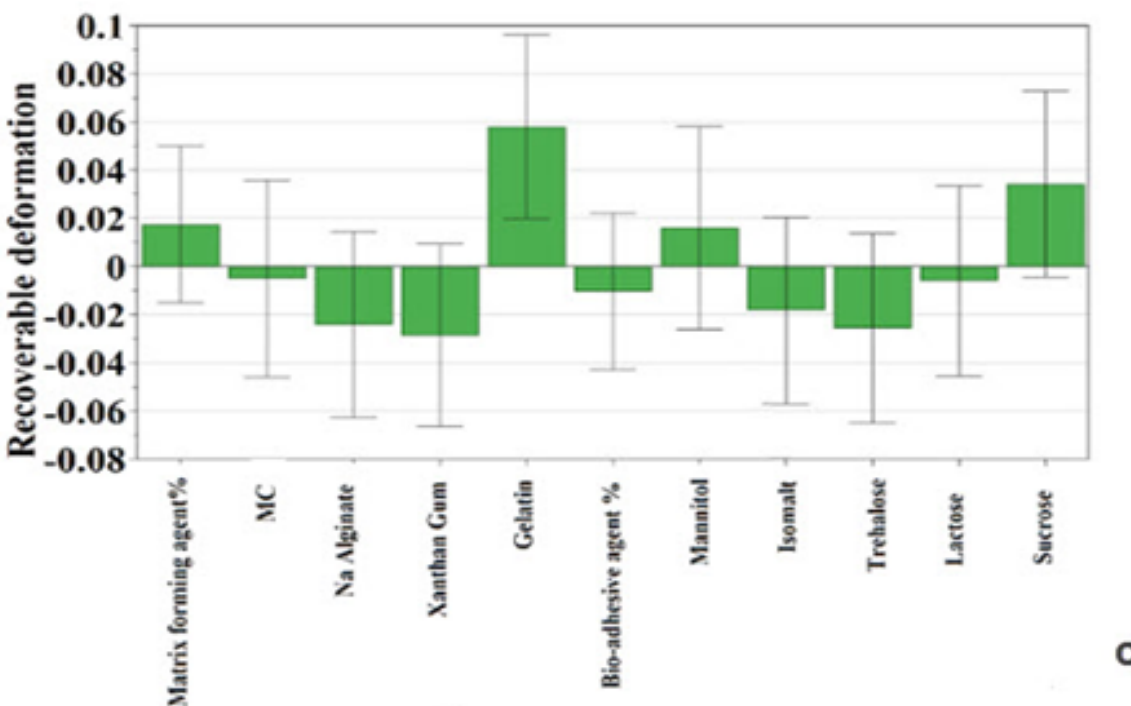

Figure 5.

Influence of the factors on the adhesiveness of the OLs (a), resilience of the OLs (b) and recoverable deformation parameter (c)

Texture analysis (Y7-Y12)

The mechanical properties of the OLs were determined by the texture testing. By applying this method, the hardness (Y7), the rigidity of the OL at $1 \mathrm{~mm}$ (Y8) and the fracturability (Y9) were determined and included into the experimental design. The influences of the formulation factors on the mechanical properties are illustrated in the Figure $3(\mathrm{~d}, \mathrm{e}, \mathrm{f})$. The hardness 
FARMACIA, 2018, Vol. 66, 3

and rigidity of the OLs were influenced by all the variables selected in this experimental design. The fracturability was influenced by the percentage of the matrix-forming agent, the percentage of the bioadhesive agent and type of the filler used.

The use of gelatine and sodium alginate conducted to resistant structures, while the usage of methylcellulose and xanthan gum conducted to fragile structures. High values of hardness and rigidity in case of gelatine OLs explain the slow disintegration and floatability. The existing studies demonstrated that the concentration of the gelatine influences the hardness and fracturability of the structures $[1,2]$.

If the increase in the bio-adhesive ratio was accompanied by the presence of filling agents, the hardness of the lyophilisates was positively influenced. Isomalt significantly increased the hardness of the OLs, while mannitol and sucrose led to structures with poor mechanical properties. The low hardness due to the use of mannitol was observed in previous studies, as well [17]. The use of HPMC and polycarbophyl has resulted in lyophilisates with higher rigidity than polyox or PVP formulations. Lyophilisates obtained with polyox or PVP had a more fragile structures.

By increasing the percentage of matrix forming agent, the fracturability of the structures raised. The fracturability or fracture resistance is determined by calculating the load value when the first fracture of the structure occurs and represents an indirect indicator for fragility of the OLs. Low values for fracturability are correlated with fragile structures [9].

The fracturability increases with high amounts of matrix forming agents, while the presence of important ratios of bio-adhesives leads to brittle structures. Out of the tested bio-adhesives, polycarbophyl has a positive effect on fracturability and rigidity; and PVP is just the opposite. As for the fillers, mannitol had a negative influence on the fracture resistance, while isomalt increased it.

Bio-adhesive properties (Y10-Y12)

The bio-adhesive properties of the OLs were studied, parameters as adhesiveness (Y10), resilience (Y11) and recoverable deformation (Y12) were determined. Bioadhesion is the necessary force of attachment of material to the mucous membrane [11]. The adhesiveness is defined as the necessary force to pull the OL away from the membrane, in this case, porcine tissue. The results are presented in Figure 5 (a, b, c) and described in the following.

The resilience is the parameter used to measure the way the material recovers from deformation in relation with the speed and forces applied; and the recoverable deformation it is referring to the height recovered by the material upon removal of the compressing force. Based on the results obtained, it was observed that by increasing the filling agent percentage the adhesiveness of the OLs decrease and the most adhesive formulations were those containing xanthan gum. The use of gelatine, as previously observed, had the most significant influence on the features of the OL. By increasing the gelatine concentration, the resilience and recoverable deformation increases. It was observed that the recoverable deformation parameter is not influenced by the selected formulation factors for this study and it can be concluded that he bio-adhesive properties of the OLs are not considerably improved by using bio-adhesive agents, and these properties can be ensured using matrix forming agents only. The matrix forming agents have slight bio-adhesive properties that are maintained throughout the lyophilization process, conferring these properties to the OLs.

Design space and optimization

Following this experiment, the correlation between the selected independent variables and the critical quality attributes were defined. A design space with the specification of QTPP was defined. Constrains were applied on the hardness and dissolution of ibuprofen at 5 minutes in order to obtain the optimum formulation having adequate mechanical properties and quick disintegration time. Regarding the statistical data analysis prediction, the optimum formulation is obtained by using sodium alginate, HPMC and trehalose in the following percentages: $0.7 \%, 0.17 \%$ and respectively $10 \%$.

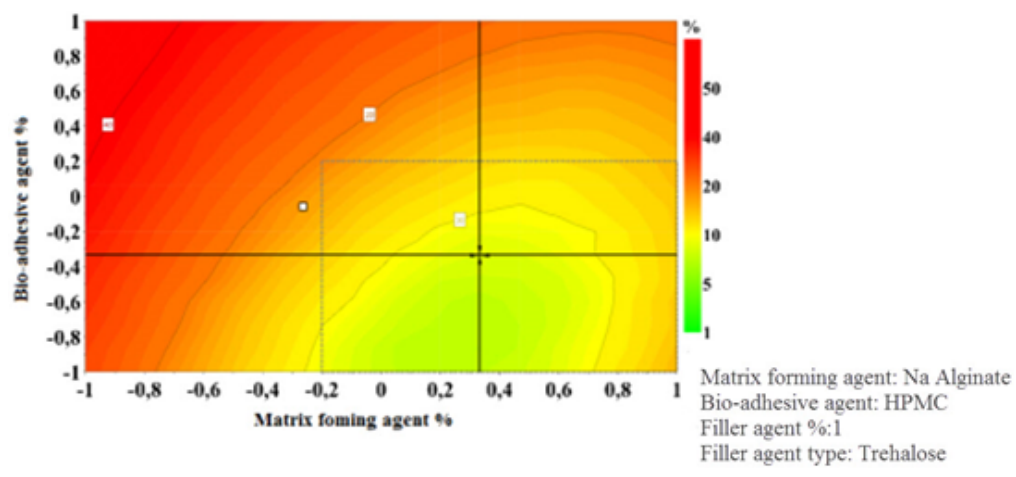

Figure 6.

Design space of optimal OL formulations 


\section{Conclusions}

The current work aimed to develop oral lyophilisates, with bio-adhesive properties containing ibuprofen as model drug, and studying the influence of formulation factors on the results obtained in their pharmaceutical characterization. Through this study, by applying the concept of $\mathrm{QbD}$, the desired product quality profile (QTPP) and critical product quality characteristics (CQA) were defined. Twenty-five experimental formulations were prepared, lyophilized and characterized, in order to identify formulation factors issues that may influence the quality characteristics of oral lyophilisates. The results revealed sodium alginate as an appropriate matrix forming agent that yields good disintegration and dissolution properties, as well as a strong porous structure. The fillers were highly beneficial to ensure fast disintegration and a compact structure. Regarding the addition of bio-adhesive agents, they seemed to prolong disintegration and dissolution, with no significant adhesion improvement. This time-effective strategy allowed us to determine the design space, and obtain oral lyophilisates with ibuprofen intended for paediatric use, having desired and predictable quality attributes.

\section{References}

1. AlHusban F, Perrie Y, Mohammed AR, Formulation of multiparticulate systems as lyophilised orally disintegrating tablets. Pharmaceutics, 2010; 2(1): 1-17.

2. AlHusban F, Perrie Y, Mohammed AR, Preparation, optimization and characterisation of lyophilised rapid disintegrating tablets based on gelatin and saccharide. Current Drug Delivery, 2010; 7: 65-75.

3. Ardelean M, Stoicescu SM, Stănescu AA, Lupuliasa D, Stănicioiu DM, Rădulescu FȘ, Miron DS, In vitro dissolution methodology and estimated consequences of biowaiver extension for immediate release solid oral dosage forms with metformin hydrochloride. Farmacia, 2018; 66(1): 18-25.

4. European Pharmacopoeia, $9^{\text {th }}$ ed. EDQM, European Pharmacopoeia, Council of Europe, France, 2014.

5. Garcia Blanes CP, Rodriguez-Canton Pascual P, Morales-Carpi C, Morales-Olivas FJ, Has the use of antipyretics been modified after the introduction of different concentrations of ibuprofen into the market?. Anales de Pediatría, 2014; 81: 383-388.

6. Gryczke A, Schminke S, Maniruzzaman M, Beck J, Douroumis D, Development and evaluation of orally disintegrating tablets (ODTs) containing Ibuprofen granules prepared by hot melt extrusion. Colloids and Surfaces B: Biointerfaces, 2011; 86: 275-284.
7. Ibrahim HK, El-Setouhy DA, Valsartan orodispersable tablets: Formulation, in vitro/ in vivo characterization. AAPS Pharm SciTech., 2010; 11(1): 189-196.

8. ICH Harmonised Tripartite Guideline: Pharmaceutical Development, Q8 (R2). www.ich.org/fileadmin/ Public_Web_Site/ICH_Products/Guidelines/Qualit y/Q8_R1/Step4/Q8_R2_Guideline.pdf

9. Iurian $\mathrm{S}$, Bogdan $\mathrm{C}$, Tomuţă I, Szabó-Révész $\mathrm{P}$, Chvatal A, Leucuţa SE, Moldovan M, Ambrus R, Development of oral lyophilisates containing meloxicam nanocrystals using QbD approach. Eur J Pharma Sci., 2017; 104: 356-365.

10. Iurian S, Turdean L, Tomuta I, Risk assessment and experimental design in the development of a prolonged release drug delivery system with paliperidone. Drug Des Devel Ther., 2017; 11: 733-746.

11. Jaipal A, Pandey MM, Abhishek A, Vinay S, Charde SY, Interaction of calcium sulfate with xanthan gum: Effect on in vitro bioadhesion and drug release behavior from xanthan gum based buccal discs of buspirone. Colloids Surf. B, 2013; 111: 644-650.

12. Jing L, Yanjiang Q, Zhisheng W, Nanosystem trends in drug delivery using quality-by-design concept. J Control Rel., 2017; 256: 9-18.

13. Khan S, Trivedi V, Boateng J, Functional physicochemical, ex vivo permeation and cell viability characterization of omeprazole loaded buccal films for paediatric drug delivery. Int J Pharma., 2016; 500: 217-226.

14. Shoukri RA, Ahmed IS, Shamma RN, In vitro and in vivo evaluation of nimesulide lyophilized orally disintegrating tablets. Eur J Pharma Biopharma., 2009; 73: 162-171.

15. Stange U, Führling C, Gieseler H, Formulation, preparation and evaluation of novel orally disintegrating tablets containing taste-masked naproxen sodium granules and naratriptan hydrochloride. J Pharma Sci., 2014; 103(4): 1233-1245.

16. Sullivan JE, Frick GS, Maxwell LG, Paul IM, Pope JF, Wells TG, Fever and antipyretic use in children. Pediatrics, 2011; 127: 580-587.

17. Takao M, Yoshinori M, Takeshi Y, Estuo Y, Katsuhide T, Formulation design of a novel fastdisintegrating tablet. Int J Pharma., 2005; 306: 83-90.

18. Vivek D, Renu BY, Richa A, Sachdev Y, Formulation design and optimization of novel fast dissolving tablet of chlorpheniramine maleate by using lyophilization techniques. Bull Faculty Pharm., Cairo University, 2017; 55: 31-39.

19. World Health Organization. Development of Paediatric Medicines: Points to Consider in Pharmaceutical Development. Working document QAS/08.257/Rev.3, (2011).

20. Yin HS, Parker RM, Sanders LM, Liquid Medication Errors and Dosing Tools: A randomized Controlled Experiment. Pediatrics, 2016; 138(4): e20160357. 